\title{
SINONIM DAN ANTONIM DALAM AL-QURAN
}

\author{
Ubaid Ridlo \\ e-mail: ubaid.ridlo@uinjkt.ac.id \\ UIN Syarif Hidayatullah Jakarta
}

\begin{abstract}
This article explains the various things about synonyms and antonyms in Arabic linguistic studies. Readers are invited to discuss cross-references on the definition of synonyms and antonyms in the Arabic linguistic context, the background of the emergence of synonyms and antonyms in Arabic, the variety of synonyms and antonyms, and the phenomenon of synonyms and antonyms in the Qur'an. Differences in understanding synonyms and antonyms result in differences in interpreting the Qur'an. Mainstream there are two kinds of pro synonyms and antonyms and counter synonyms and antonyms in the Qur "an. The argument used is the science of linguistics and exegesis, From the pro and contra of this synonym, the concept of partial synonym can be a synthesis in formulating the method of interpretation of the Qur'an. While the antonym in the context of the Qur'anic commentary is one word has two contradictory meanings. Methodology of writing this article is a qualitative approach, with approach of linguistics, and the descriptive analytical method.
\end{abstract}

Keywords:, antonim, al-Quran, fenomena, makna, sinonim

\section{PENDAHULUAN}

Bahasa terus berkembang sesuai dengan perkembangan pemikiran pemakai bahasa. Telah diketahui bahwa pemakaian bahasa diwujudkan di dalam bentuk katakata dan kalimat. Manusialah yang menggunakan kata dan kalimat, dan manusia pula yang menambah kosakata sesuai dengan kebutuhannya. Dan telah dikemukakan bahwa bahasa berkembang sesuai dengan perkembangan pemikiran pemakai bahasa. Karena manusia menggunakan kata-kata dan kalimat berubah terus, maka dengan sendiri maknanya pun berubah. Perubahan terjadi karena manusia sebagai pemakai bahasa menginginkannya. Kadang-kadang karena belum menemukan kata baru untuk mendukung pemikirannya, maka pembicara mengubah bentuk kata yang telah ada, atau boleh jadi ia mengubah makna yang telah ada.

Bahasa sebagai bagian dari fenomena sosial, dipengaruhi oleh berbagai kondisi yang dialami manusia sepanjang hidupnya. Manusia tidak akan mampu menghentikan perkembangan bahasanya atau membuatnya pada satu kondisi, karena penuturnya pun tidak dapat dibuat demikian. Karena itu, sebuah bahasa, tak terkecuali bahasa Arab, juga tidak akan lepas dari pengaruh bahasa lain. Apalagi di era globalisasi saat ini, komunikasi tanpa batas dan kemudahan interaksi antar para penutur bahasa dari berbagai bangsa, jelas mengakibatkan percepatan perubahan makna kosa kata. (Taufiqurrahman, 2008: 66)

Dalam setiap bahasa seringkali kita temui adanya hubungan kemaknaan atau relasi semantik antara sebuah kata lainnya, atau satuan bahasa dengan satuan bahasa lainnya. Relasi semantik ini pada kenyataannya berfungsi sebagai pendekatan makna dari segi hubungan pengertian. Telah kita ketahui bahwa hubungan antara tanda yang berupa lambang bunyi ujaran dengan peristiwa atau barang yang dimaksud disebut arti. Beberapa ahli bahasa berpendapat bahwa arti (meaning-bahasa Inggris) dibedakan dengan makna (sense-bahasa Inggris). 
Arti adalah apa yang disebut dengan arti leksikal (dapat dicari dalam kamus), sedang makna adalah hubungan yang ada diantara satuan bahasa.

Dalam kaitannya dengan makna, bahwa makna didapatkan dengan meneliti hubungannya dalam struktur bahasa (arti struktural). Berdasarkan kenyataan tersebut, maka dikenal bermacam-macam tata hubungan makna dalam bahasa yaitu homonim, antonim, sinonim. Berikut ini akan dibicarakan tentang sinonim dan antonim, khususnya yang ada dalam bahasa Arab dan al-Quran. Oleh karena itu, artikel ini berupaya memotret perbedaan dua istilah tersebut dan berbagai hal yang terkait dengannya.

\section{LANDASAN TEORI}

\section{Definisi Sinonim dan Antonim}

Istilah sinonim berasal dari bahasa Yunani Kuno, terdiri dari kata syn yang berarti "dengan", dan kata anoma yang berarti "nama". Jadi kalau kita kaitkan kedua kata tersebut mempunyai makan harfiyah "nama lain untuk benda yang sama" (Pateda, 2001:222). Banyak ahli bahasa yang mendefinisikan tentang sinonim ini diantaranya: Zgusta mengatakan, "Synonym : they are words which have different form but identical meaning”, sedangkan Verhar mengatakan,"sinonim adalah ungkapan (biasanya sebuah kata tetapi dapat pula frase atau malah kalimat) yang kurang lebih sama maknanya dengan suatu ungkapan lain. Contohnya kata "pandai" bersinonim denga kata "pintar" (Pateda, 2001:223).

Dalam bahasa Arab, sinonim dikenal dengan nama الترادف. Secara ردف berasal dari kata الترادف harfiyah kata yang berarti sesuatu yang mengikuti sesuatu. Sedangkata نز ادف itu sendiri berarti sesuatu yang saling mengikuti (Ibn Manzur, tt:115). Sedangkan secara etimologi, definisi الترادف menurut Dr. Taufik Muhammad Sahin: دلالة عدة ألفاظ على “ beberapa kata yang menunjukkan makna yang sama”. Contoh dalam bahasa Arab, kata القمح berpadanan dengan kata الحنطة dan البر dang berarti gandum kata البر digunakan oleh orang Irak, sedang kata القمح diucapkan oleh orang Mesir, sedang orang Makkah menyebutnya dengan kata الحنطة (Sahin, 1980:216).

Sedangkan Imam Fakhruddin الألفاظ المفردة dengan الترادف medefinisikan

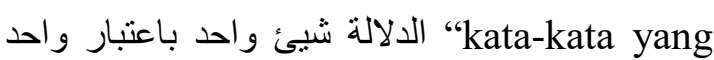
menunjukkan pada sesuatu yang sama dengan satu ungkapan”. Menurutnya, kata الترادف denagn kata الصسارم bukanlah karena keduanya menunjukkan pada sesuatu yang sama, namun mempunyai dua ungkapan, السيف merupakan zat, sedang الصارم adalah sifatnya. Ia 
mencontohkan kata الإنسان dengan kata karena pengertian kata yang kedua (البشر) menguatkan kata yang pertama (الإنسان) (al-Suyuti, tt: 402).

Al-Dawa'i menjelaskan sinonim dengan dua pengertian, Pertama, تعدد الوضع وتوسيع داؤرة التعبير وتكثير وسائله sinonim merupakan banyaknya kata yang dapat diungkapkan dengan berbagai cara. Kedua, تسهيل تادية بإحدى العبارتين عند تساةى (Ali Sami, 1966:34-35), Pengertian kedua ini mengandung tujuan adanya sinonim yakni mempermudah pencapaian suatu maksud tertentu, pada salah satu dari dua ungkapan ketika mempunyai arti yang sama dengan yang lain.

Dengan demikian, mengutip pendapat Taufiqurrahman, sinonim ( $A l$ Taraduf) adalah dua kata atau lebih yang maknanya kurang lebih sama. Dikatakan "kurang lebih" karena memang tidak ada dua buah kata berlainan yang maknanya persis sama. Sebenarnya yang sama adalah informasinya saja, sedangkan maknanya tidak persis sama. Misalnya, kata jenazah, bangkai, mayat, kata-kata ini disebut bersinonim namun kata-kata ini tidak persis sama maknanya. Buktinya kata-kata yang bersinonim tidak bebas dipertukarkan secara bebas. Misalnya, “aku melihat bangkai anjing”, tidak bisa ditukar dengan "aku melihat jenazah anjing” (Taufiqurrahman, 2008:73).

Sedangkan antonim berlawanan dengan sinonim. Kata antonim berasal dari bahasa Yunani Kuno, yaitu onoma berarti nama dan anti bermakna melawan . Secara harfiah berarti kata ysng mengandung makna yang berlawanan atau berkebalikan dengan kata yang lain (Guntur Tarigan, 1995:25).

Dalam bahasa Arab antonimi dikenal dengan istilah التضاد atau الأضداد merupakan bentuk jamak dari ضyang berarti sesuatu yang berlawanan dengan yang lain, seperti السواد (hitam) yang berantonim dengan البياض (putih). الحي (mati) yang berantonim dengan الموت (hidup) (Ibn Manzur, tt: 45).

Para ahli bahasa Arab mendefinisikan antonimi dengan ungkapan yang berbeda-beda, namun demikian merujuk pada satu pengertian yang sama. Dr. Amil Badi' Ya'kub (guru besar Fiqh Lughah Universitas Libanon) misalnya mendefinisikan antonimi dengan menggunakan satu kata atau dua pengertian yang berlawanan. Dalam konteks ini antonimi merupakan bagian dari homonimi (المشترك اللفظى). Lebih lanjut beliau menjelaskan bahwa setiap antonimi merupaka homonimi tetapi tidak sebaliknya. Contoh : المولى yang berarti العبد (hamba) dan juga السيد (tuan). Dan 
الأسود yang berarti الأبيض datih) dan (hitam) (Amil Badi', tt:387).

Selain pengertian di atas terdapat pengertian lain dari al-Tadhad yaitu satu kata yang memiliki dua makna yang berlawanan, seperti "المختار" dapat bermakna yang memilih juga yang dipilih. " dapat bermakna cahaya juga kegelapan. "لجليل" dapat bermakna biasa (mudah) juga agung (Majid Tharad, tt:5).

Para linguis Arab lebih banyak cenderung menulis tentang al-Tadhad pada makna yang kedua, adapun para linguis yang pertama mengarang kitab tersebut yang diberi judul " الأضداد" yaitu Muhammad al-Mustanir al-Ma'ruf (206 H/821 M), Abu Abidah (209 H/823 M), dan Dr. Antonius Batros "Qatrab". Adapun karangan-karangan mengenai $a l$ Tadhad pengertian yang kedua sangat jarang sekali. Dengan demikian antonim (al-tadhad) adalah dua buah kata atau lebih yang maknanya 'dianggap' berlawanan. Disebut dianggap karena sifat berlawanan dari dua kata yang berantonim ini sangat relatif. Ada katakata yang mutlak berlawanan, seperti kata mati dengan hidup. Kata siang dengan malam. Ada juga yang tidak mutlak, seperti kata jauh dengan dekat, kata kaya dengan miskin. Seseorang yang 'tidak kaya' belum tentu 'miskin'. Begitu juga sesuatu yang tinggi belum tentu tidak rendah

Sebenarnya bukan hanya bahasa Arab yang memiliki fenomena kebahasaan semacam ini (baca: antonimi), Bahasa-bahasa lain juga memiliki hal yang sama. Seperti dalam bahasa Latin dikenal dengan kata "altus" yang berarti tinggi dan dalam, dan istilah "tuer" yang artinya memelihara sekaligus membunuh dan mati dalam bahasa Perancis.

\section{Latar Belakang Munculnya Sinonim}

\section{dan Antonim}

Sinonim bisa terjadi antara lain, sebagai akibat adanya:

a. Pengaruh kosakata serapan (dakhil) dari bahasa asing

Misalnya, dalam bahasa Arab kontemporer dikenal kata التلفون (telepon) yang aslinya dari bahasa Eropa dan kata الهنيف yang merupakan ta'rib (terjemahan ke Arab) sehingga kata itu dianggap sinonim. Contoh lain, kata التيلفزون sinonim dengan kata الإذاعة المرئية, kata تياتزو kata الحاسوب dengan kata الكمبيونير (dari bahasa Itali) sinonim dengan kata مسرح (drama). Sekalipum kosakatakosakata tersebut dianggap sinonim, namun bebarapa konteks tidak bisa disebut sinonim. Misalnya, kata مسرح (drama kejahatan) tidak bisa ditukar dengan الجريمة نياتزو, sebab maksud 
dari "drama kejahatan" adalah kronologi terjadinya kejahatan, bukan drama atau penampilan tentang kejahatan.

\section{b. Perbedaan dialek sosial (infialiyah)}

Misalkan kata istri bersinonim dengan kata bini. Tetapi kata istri digunakan dalam kalangan atasan sedangkan bini dalam kalangan bawahan. Dalam bahasa Arab, kata (مجدد pembaharu) memiliki makna positif, berkelas tinggi dan diterina di beberapa negara Arab. Akan tetapi, kقدمي tidak bisa ditukar dengan مجدد atau ثوريwalaupun ketiganya bersinonim. Sebab, kata تقدي memiliki makna yang mencerminkan seseorang reaksioner, pemberontak dan sebagainya, walaupun di beberpa wilayah Arab kedua kata ini tetap digunakan.

\section{c. Perbedaan dialek regional (lahjah iqlimiyah)}

Misalnya, kata handuk bersinonim dengan kata tuala, tetapi kata tuala hanya dikenal dibeberapa daerah Timur saja. Dalam سيارة نقل kahasa Arab, misalnya, kata (truk) hanya dikenal di Mesir, sementara di negara-negara Arab bagian teluk dan Maroko lebih mengenal kata شاحنة . Contoh lain, istilah 'pom bensin' orang محطة Mesir menyebutnya dengan kata طلمبة orang Sudan menyebutnya dan orang Irak mengenalnya بنزينخانة بينة

\section{d. Perbedaan dialek temporal}

Misalnya, kata hulubalang bersinonim dengan kata komandan, tetapi kata hulubalang hanya cocok digunakan dalam suasana klasik saja. Contoh lain, kata المدرسة الأبتدائية bersinonim dengan الكتاب sama-sama berarti "sekolah dasar". Akan tetapi, istilah الكتاب hanya dipakai pada masa lampau (Taufiqurrahman, 2008:7475).

Sedangkan munculnya antonim sebagai akibat dari adanya hal-hal berikut:

a. Perbedaan penggunaan suatu lafadz oleh suku-suku Arab, seperti kata " bermakna gelap menurut suku Tamim, dan terang menurt suku Qais. Kata "قرأ Bermakna suci menurut orang hijaj dan bermakna haid menurt orang Irak. Kata kerja "سجد" bermakna berdiri tegak bagi suku Thoyyi' dan membungkuk menurut kebanyakan suku. Dan kata kerja "وثب" bermakna duduk menurut Himyar di Yaman dan meloncat menurut seluruh orang Arab (alAnbari, tt:91-294).

b. Dilalah suatu kata yang pada asli pembentukannya memiliki dua makna yang berbeda, jika terdapat lafadz atau kata yang memiliki dua makna yang bertentangan maka 
sebenarnya bermakna satu, contohnya

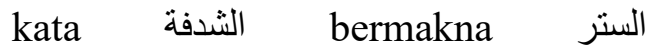
(penghalang), maka siang ketika tiba malam cahayanya akan terhalangi oleh gelapnuya malam, begitu pula gelapnya malam ketika tiba pagi hari akan tertutupi oleh cahaya siang. الجلل kata lain seperti kata bermakna mudah (biasa) juga agung (luar biasa), karena suatu yang bisa menjadi luar biasa bagi orang yang lebih biasa darinya. Begitu juga sebaliknya sesuatu yang besar menjadi kecil jika disandingkan dengan yang lebih besar darinya.

c. Perkembangan fonetik suatu kata dan Tashif , contoh kata kerja “ زبر" bermakna menulis dan membaca, hal itu terjadi dikarenakan kata kerja “ زبر" yang bermakna menulis, fonetik "ذ" berkembang menjadi “ز” maka menjadi “زبر" maka secara kebetulan kata Persia yang diarabkan "زبر" yang bermakna membaca, maka kedua tersebut disatukan maknanya menjadi zabara yang memiliki dua arti, menulis menurut orang Arab dan membaca menurut orang Persi (Muhammad Hasan, tt:159).

d. Kesesuaian dua kata dalam satu bentuk morfologis, seperti pada sighah berikut:
1. Fa'il, terkadang terdapat sebagian kata yang bentuk morfologisnya fa'il digunakan untuk fa'il dan maf'ul. Contoh, kata "خائف" dapat bermakna يخاف juga المخفوف.

2. Fa'ulun, terdapat sebagian kata yang berbentuk fa'uulun dimaksudkan untuk fa'il dan maf'ul. Contoh, "ركوب" bermakna yang mengendarai dan dikendarai.

3. Fa'iilun, terdapat sebagian kata yang berbentuk Fa'iilun dimaksukan untuk fa'il dan maf'ul. Contohnya, "السميع" bermakna yang mendengar juga yang didengarkan.

4. Mufta'alun, untuk shighah fa'il dan maf'ul, contohnya al-mukhtar dapat bermakna yang memilih juga yang dipilih.

\section{Ragam Sinonim dan Antonim}

Para ahli bahasa membagi sinonim berbeda-beda, misalnya Dr, Ahmad Mukhtar Umar (1982:220-222), ia membagi menjadi 7 bagian:

1. Perfect Synonymy (الترادف الكامل), ini terjadi ketika ada dua kata yang berbeda atau lebih, mempunyai kesamaan makna yang sempurna/mutlaq, sehingga tidak dapat dirasakan adanya perbedaan antara keduanya. Sinonim jenis ini sangat 
jarang terjadi, bahkan hampir tidak ada.

2. Near Synonymy (شبه الترادف) ini dapat terjadi jika dua kata mempunyai kedekatan makna yang amat dekat sehingga sulit bagi kita untuk membedakannya, karena sering digunakan hingga mengabaikan perbedaan kedua kata tersebut. Contoh: (حول-عام-سنة.

3. Relasi Semantik (التقارب الدلالى) ini terjadi ketika makna saling mendekati, namun antara kata yang satu dengan yang lain berbeda, tetapi ada satu aspek inti yang menjadikan antara kata yang satu dengan yang lainnya masih dalam tatanan arti yang sama. Contoh dalam bahasa Inggris, kata crawl - kip - hop - run-walk. Semua kata tersebut mengandung arti bergerak dengan menggunakan kaki, namun cara menggerakkan, jumlah kaki yang digunakan antara kata yang satu dengan kata yang lainnya berbeda.

4. Entailment (استلزام), hubungan sebab akibat, dapat dilihat dari contoh berikut:

Pernyataan I: Muhammad bangun dari tempat tidunya jam 10.

Pernyataan II: Muhammad ada di tempat tidurnya sebelum jam 10 .
Jadi pernyataan II merupakan entialment pernyataan I.

5. Paraphrase (الجمل المترادفة), ini terjadi ketika dua kalimat mempunyai arti yang sama, contoh:

a. Saya membeli alat tulis dari Muhammad seharga 100 dinar.

b. Muhammad menjual padaku alat tulis seharga 100 dinar.

6. Terjemah (الترجمة), ini terjadi ketika dua ungkapan/dua kalimat memiliki arti yang selaras dalam dua bahasa yang berbeda, atau dalam satu bahasa namun tingkat khitabnya berbeda, seperti pada penerjemahan tulisan ilmiyah ke dalam tulisan biasa atau penerjemahan syair ke dalam prosa.

7. Interpretasi/penafsiran (التفسير

Sedangkan Para ahli bahasa mengklasifikasikan antonimi menjadi beberapa bagian.

1. Ahmad Mukhtar Umar (1982:membagi antonimi menjadi lima yaitu:

a. Antonimi ungradable / nongradable disebut juga antonomi komplementer yaitu pasangan yang saling melengkapi seperti kata hidup dan mati. 
b. Antonimi gradable yaitu apabila penegatifan suatu kata tidaklah bersinonim dengan kata lain atau adanya tingkatan kwalitas kata berantonimi. Disebut juga dengan antonimi bertingkat misalnya (cuaca pana) berantonimi denga (cuaca dingin). Tetapi karena kenisbian sifat cuaca maka dapat dikatakan pula bahwa antonimi dari cuaca panas bukan hanya cuaca dingin melainkan juga cuaca sejuk.

c. Antonimi bekebalikan (converseness) / العكس yaitu pertentangan yang terjadi antara objek-objek yang masih memiliki keterkaitan satu dengan yang lainnya. Contoh: menjual dengan membeli dan suami dengan istri. Jika dikatakan bahwa Muhammad menjual rumah kepada Ali, ini berarti bahwa Ali membeli rumah dari Muhammad.

d. Antonimi direksional (إتجهى) yaitu pertentangan makna yang menunjukan posisi, keadaan, tempat atau arah yang berbeda-beda. Antonimi ini terbagi menjadi dua yaitu orthogonal opposites dan antipodal opposites. Yang dimaksud dengan orthogonal opposites yaitu pertentangan yang saling bertolak belakang satu sama lain misalnya utara yang berantonimi dengan selatan, timur dengan barat. Sedangkan antipodal opposites adalah pertentangan antara dua atau lebih arah, posisi dan keadaan. Misalnya utara yang berantonimi dengan selatan, barat dan timur dan kanan yang berantonimi dengan kiri, depan dan belakang.

2. A. Chaer membagi antonimi menjadi :

a. Antonimi yang bersifat mutlak, seperti hidup dan mati

b. Antonimi yang bersifat relatif, seperti besar dan kecil

c. Antonimi yang bersifat relasional seperti penjual dan pembeli

d. Antonimi hieralkal seperti gram dan kilogram.

3. Al-Khammas, dalam Taufiqurrahman (2008:75-78) mengklasifikasi antonim menjadi 3 (tiga) macam, yaitu:

a. Antonim Mutlak (Tadhoh Had)

Yaitu, diantara medan makna pada dua kata yang berlawanan tidak tepat tingkatan/level. Artinya, kedua kata yang maknanya berlawanan itu benar-benar mutlak. Contoh:

\begin{tabular}{|l|r|l|c|}
\hline Betina/perempuan & $\begin{array}{l}\text { Jantan/laki- } \\
\text { laki }\end{array}$ & \\
\hline Menikah & Bنزىوج & Bujang & أعزب \\
\hline
\end{tabular}




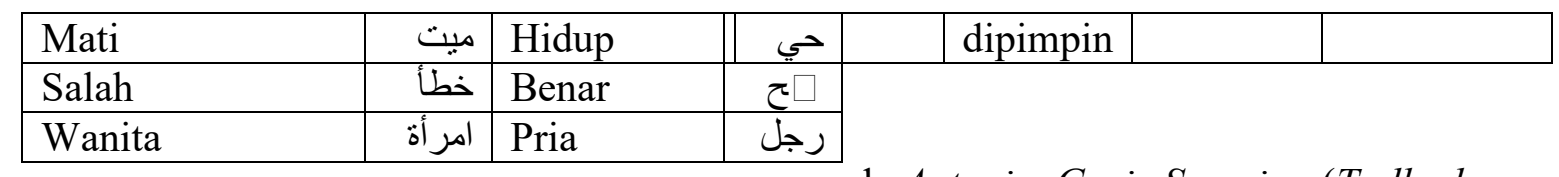

b. Antonim bertingkat (Tadhad

\section{Mutadarrij)}

Yaitu, diantara medan makna pada

2 kata yang berlawanan masih terdapat tingkatan/level. Artinya, makna dari kata-kata yang saling berlawanan masih relatif. Contoh:

a. سهل (mudah) lawan kata (sulit); namun antara 'mudah' dan 'sulit' masih tingkat kemudahan atau kesulitan tertentu.

b. بار (dingin) lawan kata حارد (panas); diantara 'panas' dan 'dingin' masih ada level tertentu. Misalnya: فاتر (hangat kuku), (hangat), دافئ (paling hangat).

c. Antonim Berlawanan (Tadhad Aksiy)

Yaitu, diantarra medan makna pada dua kata yang berlawanan bersifat lazim/lumrah. Contoh:

\begin{tabular}{|c|c|c|c|}
\hline $\begin{array}{c}\text { اب } \\
\text { Ayah }\end{array}$ & $\begin{array}{l}\text { l } \\
\text { Ibu }\end{array}$ & $\begin{array}{c}\text { زوج } \\
\text { Suami }\end{array}$ & زوجة \\
\hline ام & اشتري & اعطى & اخذ \\
\hline Menjual & Membeli & Memberi & Mengambil \\
\hline Mengajar & تعلم & $\begin{array}{l}\text { و الدة } \\
\text { Ibu }\end{array}$ & $\begin{array}{l}\text { مولود } \\
\text { Anak }\end{array}$ \\
\hline $\begin{array}{c}\text { رئيس } \\
\text { Pemimpin }\end{array}$ & $\begin{array}{l}\text { مر عوس } \\
\text { Yang }\end{array}$ & $\begin{array}{c}\text { فائز } \\
\text { Menang }\end{array}$ & $\begin{array}{l}\text { مهوز } \\
\text { Kalah }\end{array}$ \\
\hline
\end{tabular}

d. Antonim Garis Samping (Tadhad Amudiy)

Yaitu, apabila kata-kata yang antonim (berlawanan) tersebut terdiri dari kosakata yang bersifat arah (directon). Kosakata yang berlawanan menurut garis menyimpang disebut antonim garis samping. Misalnya, شمال (utara) lawan kata شزق (timur), غرب (selatan) lawan kata) جنوب (barat), غرب (barat) lawan kata شمال (utara).

Perhatikan gambar berikut:

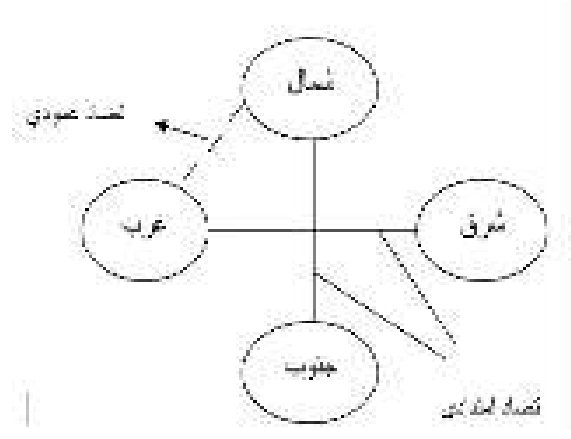


غرب timur) lawan kata) شزق (barat), فوق (diatas) lawan kata تحت (dibawah). (Taufiqurrahman, 2008:75-78). Dibawah ini tabel kata-kata antonim dalam bahasa Arab:

\begin{tabular}{|c|c|c|}
\hline أظهر & ستر & أخفى \\
\hline مات & استراح & أراح \\
\hline أبطأ & أسرع & أفذ \\
\hline الشجاعة & الخوف & البأس \\
\hline اشترى & باع & باع \\
\hline الأعمى & المبصر & البصير \\
\hline سأل & أعطى & تصدَق \\
\hline العبد & المِلك & الجبر \\
\hline الصغير & الأبيض & الجون \\
\hline اليقين & الشك & حسِب \\
\hline الساخن & البارد & الحميم \\
\hline المتحرك & الساكن & الدائم \\
\hline الواحد & الاثنان & الزَواج \\
\hline أصلح & أفسد & عاث \\
\hline زاد & زال & عفا \\
\hline
\end{tabular}

\section{METODE PENELITIAN}

Metodologi penulisan artikel ini adalah melalui pendekatan kualitatif, dengan pendekatan ilmu linguistik, dan dengan metode deskriptif analitis
HASIL DAN PEMBAHASAN

Fenomena Sinonim dan Antonim dalam al-Quran

Pandangan yang menetapkan adanya sinonimi dalam al-Qurean diantaranya didasarkan pada riwayat alBukhari dalam Shahih al-Bukhari Kitab Fadhāilu al-Qur'ān bab Unzila al-Qur'ān 'alā Sab'ati Akhrufin'. Bahwasanya Rasulullah Saw bersabda „sesungguhnya al-Qurean ini diturunkan atas tujuh macam bacaan (sab'atu akhrufin), maka bacalah apa yang termudah darinya ${ }^{e e}$. (2) sinonimi merupan bentuk taukīd (penguatan) dalam al-Qur'an, seperti lafadz „fijājān subulān' dalam surat alAnbiyā' [21]: 31 (3) Sinonmi merupakan bagian dari al-mutasyābih (penyerupaan) dalam al-Qurean. Dimana diantara bentuk al-mutasyābih dalam al-Qur ${ }^{\text {ecan adalah }}$ penggantian suatu kata dengan yang lain dalam dua ayat yang serupa misalnya dalam surat al-Baqarah [2]: 170, 'mā alfainā 'alaihi ābā'anā dan surat Luqman [31]: 21 'mā wajadnā 'alaihi ābā'anā'. (alMunajjad, 1997: 109-118).

Tidak sependapat dengan pandangan mengenai adanya sinonimi dalam al-Qur'an, kelompok kontra sinonimi dalam al-Qur'an menjelaskan argumentasinya sebagai berikut; (1) AlQurean ini diturunkan atas tujuh macam bacaan (sab'atu akhrufin) tidaklah 
menunjukkan bahwa di dalam al-Qurean ada sinonimi karena meskipun adanya kesamaan makna dengan lafadz yang berbeda akan tetapi ia dari berbagai dialek yang berasal dari suku yang berbedabeda. Karena itulah sebagian orang Arab tidak dibebani berpindah dari dialek mereka kepada dialek dimana al-Qur'an diturunkan karena hal itu akan menimbulkan kesulitan bagi mereka. (2) Tidak ada lafadz yang bisa menempati selain tempatnya. Tidak ada beberapa lafadz dengan satu makna, kecuali karena adanya perbedaan dialek. Apa yang disangka sebagai sinonimi sesungguhnya bukan sinonimi. Ada kekhususan setiap ungkapan dari berbagai lafadz yang tidak ada pada selainnya, meskipun kekhususan atau perbedaan itu sangat samar sifatnya. (al-Munajjad, 1997: 115-124)

Al-Qur'an banyak memakai kosa kata yang pada lahirnya tampak bersinonim, namun bila diteliti secara cermat ternyata masing-masing kosa kata itu mempunyai konotasi sendiri-sendiri yang tidak ada pada lafal lain yang dianggap bersinonim dengannya. Di antara ayat-ayat yang terkesan bersinonim itu ialah Q.s Ar-ra'd: 21

وَالَّنِْينَ يَصِلُونَ مَا أََْرَ اللَّهُ بِهِ أَنْ يُوصَلَ

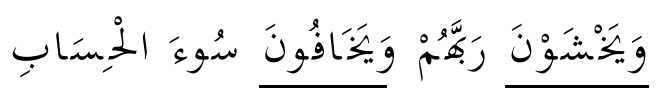

Kata khasyyah dan khawf hampir tidak berbeda pemahamannya secara lughawi. Tetapi al-Qur'an memakai kata tersebut dalam konotasi yang berbeda. Penggunaan kata khasyyah dalam alQur'an lebih mengacu pada perasaan takut yang disertai hormat dan mengagungkankarena pada umumnya kata ini selalu dikaitkan dengan perasaan takut kepada Allah. Walaupun seseorang itu mempunyai mental yang kuat, sudah pasti dia tidak akan berdaya jika dikaitkan urusannya dengan Allah. Sedangkan kata khawf berarti rasa takut yang wajar. Karena, rasa takut tersebut bisa muncul akibat dari sebab yang jika dilakukan oleh seseorang. Seperti halnya rasa takut pada siksa di akhirat kelak karena seorang tersebut sering melakukan dosa. (Baidan, 2005: 317-318)

\section{Q.s al-Maidah: 3}

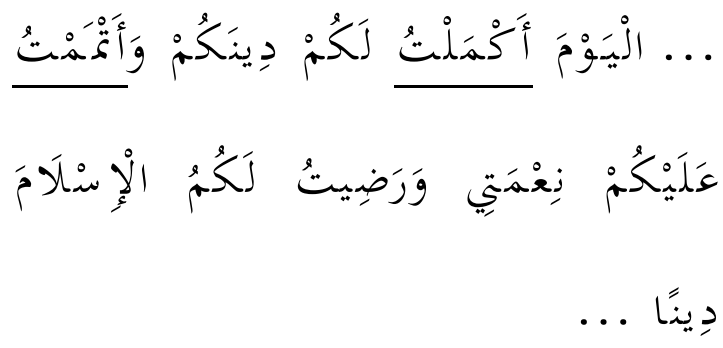

Lafal kamal dan tamam pada ayat di atas sepintas lalu terkesan konotasi keduanya sama, jika pada kata tamam pada awalnya tidak memakai “و" (harf 'athf) yang menghubungkan kalimat akmaltu dengan atmamtu, karena 
pemakaian harf 'athf menunjukkan bahwa kedua kalimat tersebut mempunyai makna yang berbeda. Dengan demikian timbul kesan bahwa antara ikmal dan itmam tidak bersinonim, melainkan mempunyai konotasi yang berlainan. (Baidah, 2005: 320), Dalam kaitan inilah Al-'Asykari sebagaimana dikutip oleh al-Zarkasyi berkata: "alkamal adalah sebutan bagi suatu objek yang seluruh bagiannya telah berhimpun secara utuh, dan al-tamam ialah nama bagi sub-sub bagian yang membentuk objek tersebut". Dari itu maka pemahaman ayat 3 surat al-Maidah tersebut ialah: Allah telah memberikan agama yang sempurna lagi utuh dan nikmat yang sudah lengkap kepadamu. (al-Zarkasyi,tt: 85).

Dengan demikian, dari pendapat dan contoh di atas dapat disimpulkan bahwa sinonim utuh dalam al-Quran itu tidak ada.

Demikian juga dengan antonim, sekalipun ada penolakan mengenai adanya antonimi tidak sedikit juga ahli yang tetap berpendirian bahwa bagaimana pun juga konsep antonimi dengan musytarik lafdzi adalah tidak sama. Ketidak samaan itu jelas terletak pada sisi makna yang "bertentangan". Para ahli lughah yang tetap berpandangan bahwa antonimi merupakan konsep relasi makna tersendiri, sedikit besarnya dikarenakan al-Qur'an sendiri memuat banyak bentukbentuk kata berpola antonimi. Dan mereka menganggap bahwa konsep antonimi ini adalah salah satu bukti, bahwa konsep linguistik dalam al-Qur'an jauh lebih komplek dan lengkap dibandingkan dengan konsep linguistik yang lain. Berikut ini ada beberapa contoh kata yang berbentuk antonimi dalam al-Quran, di antaranya adalah;

Kata, الأشتراء Kata ini memiliki dua arti yang bertentangan yaitu arti yang pertama adalah “membeli” (الابتياء), pengertian ini dapat dilihat dalam surat atTaubah: 111. Perhatikan ayat berikut ini;

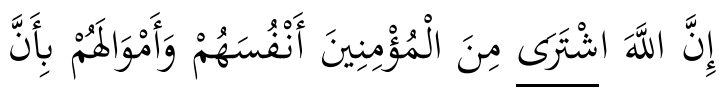

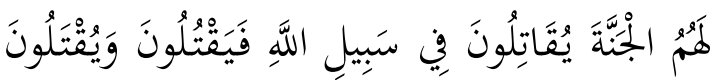

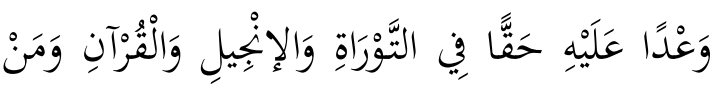

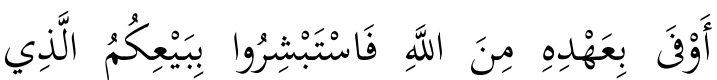
بَايَعْتُمْ بِهِ وَذَلِكَ هُوَ الْفَوْزُ الْعَظِيمُ "Sesungguhnya, Allah telah membeli dari orang-orang mu'min, diri dan harta mereka dengan memberikan surga (sebagai balasan) untuk mereka. Mereka berperang pada jalan Allah, lalu mereka membunuh atau terbunuh. (Itu telah menjadi) janji yang benar dari Allah di dalam Taurat, Injil dan al-Qur'an. Dan 
siapakah yang lebih menepati janjinya (selain) daripada Allah? Maka bergembiralah dengan jual beli yang telah kamu lakukan itu, dan itulah kemenangan yang besar."

Arti, الأشتراء yang kedua adalah “ menjual" (باعو .) Pengertian ini terdapat dalam surat al-Baqarah: 90:

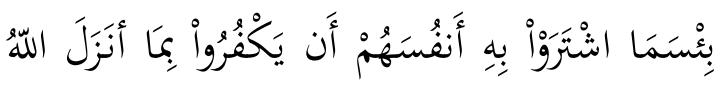
بَغْيَاً أَنْ يُنَبِّلُ اللهُ مِن فَضْلِهِ عَلَى مَن يَشَاءُ مِنْ عِبَادِهِ فَبَاَؤُواْ بِغَضَبِ عَلَى غَضَبِ وَلْلْكَافِرِينَ

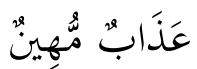
"Alangkah buruknya (perbuatan) mereka, dimana mereka menjual dirinya sendiri dengan mengingkariapa yang telah Allah turunkan (kepada Muhammd) karena dengki; padahal Allah menurunkan karunia-Nya (Kitab Suci) kepada siapa yang Dia kehendaki diantara hamba-hamba-Nya. Karena itu mereka menanggung kemurkaan demi kemurkaan. Dan untuk orang-orang kafir (disiapkan) siksaan yang menghinakan".

Kata ظن, kata ini juga memiliki arti yang berlawanan yaitu "yakin" (يقين) dan "kira-kira: atau "ragu" (شك).
Pengertian yang pertama dapat dilihat dalam surat al-Baqarah: 45-46 dan alHaaqah:20;

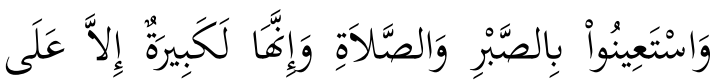

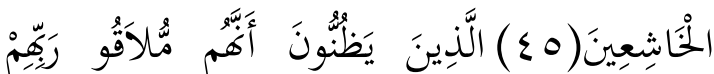

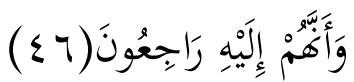

Artinya: Jadikanlah sabar dan shalat sebagai penolongmu. Dan Sesungguhnya yang demikian itu sungguh berat, kecuali bagi orangorang yang khusyu', (yaitu) orang-orang yang meyakini, bahwa mereka akan menemui Tuhannya, dan bahwa mereka akan kembali kepada-Nya (QS. al-Baqarah: 45-46).

Pada ayat yang lain disebutkan;

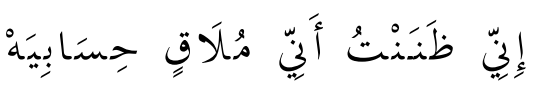

Artinya: Sesungguhnya aku yakin, bahwa sesungguhnya aku akan menemui hisab terhadap diriku. (al-Haaqqah: 20)

Sementara kata ظن juga bisa berarti ragu (شك) seperti yang terdapat dalam surat alJasyiyah berikut ini; 


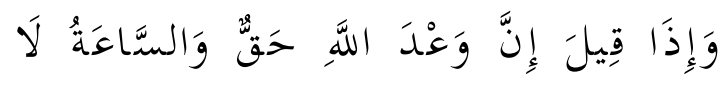

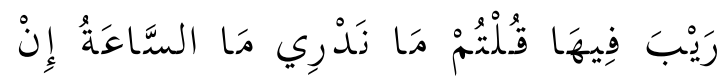

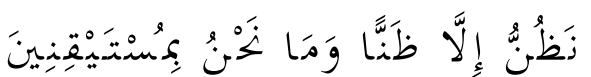

Artinya: Dan apabila dikatakan (kepadamu): "Sesungguhnya janji Allah itu adalah benar dan hari berbangkit itu tidak ada keraguan padanya", niscaya kamu menjawab: "Kami tidak tahu apakah hari kiamat itu, kami sekali-kali tidak lain hanyalah menduga-duga saja dan kami sekali-kali tidak meyakini(nya)". (al-Jatsiyah: 32)

\section{SIMPULAN DAN SARAN}

Dari uraian tentang sinonim dan antonim dalam al-Qur'an di atas, maka dapat disimpulkan bahwa terjadi silang pendapat tentang adaanya fenomena sinonim dan antonim dalam al-Quran. Penggunaan sinonim dan antonim dalam ungkapan yang berbeda adalah bukti keagungan dan mukjizat al-Quran. Apabila Al-Qur'an dibaca, maknanya akan jelas. Tetapi bila dibaca sekali lagi, maka akan ditemukan pula makna-makna lain yang berbeda dengan makna sebelumnya, demikian seterusnya, sampai-sampai anda (dapat) menemukan kalimat atau kata yang mempunyai arti bermacam-macam. Semuanya benar atau mungkin benar. Ayat-ayat Al-Qur'an bagaikan intan. Setiap sudutnya memancarkan cahaya yang berbeda dengan apa yang terpancar dari sudutsudut lain, dan tidak mustahil, jika anda mempersilahkan orang lain memandangnya, maka dia akan melihat lebih banyak dari apa yang anda lihat. Oleh karena itu, perlu pemahaman yang mendalam terhadap konteks ayat dan berbagai macam instrumen keilmuan ilmu tafsir al-Quran terhadap semantika sinonim dan antonim dalam al-Quran..

\section{DAFTAR PUSTAKA}

Taufiqurrochman, 2008. Leksikologi Bahasa Arab, UIN-Malang

Majid Thatad, al-Mu'jam al-Mufashal fi al-Mutaradifatfi al-lughah alArabiyah, Daar el Kutub Alamiyah

Mansoer Pateda. 2001. Semantik Leksikal, Jakarta: Rineka Cipta,

Henry Guntur Tarigan. 1995. Pengajaran Semantik, Bandung: Angkasa,

Abdul Chaer. 1995. Pengantar Semantik Bahasa Indonesia, Jakata: Rineka Cipta

Al-Nasyar, Ali Sami. 1966. Manahij alBahtsinda Mufakkiri al- Islam, Kairo: Dar Ma'rifat.

Askari, Abu Hilal. 1973. al-Furuq fi alLughah, Beirut: Dar al-Afaq alJadidah Manzur, Ibn. Tt. Lisan alArab, Beirut: Dar Shadir, jilid 9.

Al-Zarkasyi. tt. Al-Burhan fi 'Ulum AlQur'an, Tahqiq, Muhammad Abu Al-Fadhl Ibrahim, Mesir: 'Isa alBab al- Halabi Ramdhan Abd. AtTawwab. Tt. Fush $l$ fi Fiqh alLughah, Kairo: Maktabah al-Khanji 
Chaer, Abdul. 2007. Linguistik Umum. Jakarta: Rineka Cipta

Djajasudarma, T. Fatimah. 2012. Semantik 1; Makna Leksikal dan Gramatikal. Bandung: PT Refika AditamSahin, Taufik Muhammad. 1980. al-Musytarak al-Lughawy Nazhariyah wa Tathbiqiyyah, Kairo: Maktabah Wahbah

Hornby, AS. Oxford Advanced Learner's Dictionary (7th edition). New York: Oxford University Press.

Jinny, Ibnu. 1988, al-Khashaish, Mesir: al-Haiah al-Mishriyah al-Amah li al-Kitab.

Kridalaksana, Harimurti. 2008. Kamus Linguistik, Edisi Keempat, Jakarta: Gramedia

Matthews, P.H. 1997. The Concise Oxford Dictionary of Linguistics. New York: Oxford University Press.

Munajjad, Muhammad Nuruddin al, 1997, at-Taraduf fi al-Qur"an al-Karim: bain al-Nadhariyah wa al-Tathbiq, Damsyiq: Dar al-Fikr

Nashruddin Baidan. 2005. Wawasan Baru Ilmu Tafsir, cet 1, Yogyakarta: Pustaka Pelajar

Pateda, Mansoer. 2001. Semantik Leksikal. Jakarta: PT Rineka Cipta

Palmer, F.R. 1976, Semantic, Combridge: Combridge University Press.

Umar, Ahmad Mukhtar. 1982. Ilmu adDalalah. Kuwait: Dar al- Arubah.

Ullmann, Stephen. 1972. Semantics an Introduction to The Science of Meaning. Oxford: Basil Blackwell

Verhaar, J.W.M. 1983. Pengantar Linguistik. Yogyakarta: Gadjah Mada University Pres

Wijana, Dewa Putu dan Muhammad

Rohmadi. 2008. Semantik (Teori dan

Analisis). Surakarta: Yuma Pustaka. 